\title{
Plankton community structure and trophic interactions in a shallow and eutrophic estuarine system, Ariake Sound, Japan
}

\author{
Yasuo Nakamura ${ }^{1, *}$, Atsuhiro Hirata ${ }^{2}$ \\ ${ }^{1}$ National Institute for Environmental Studies, Onogawa, Tsukuba, Ibaraki 305-8506, Japan \\ ${ }^{2}$ Marine Biological Research Institute of Japan Co., Ltd., Yutaka-cho 4-3-16, Shinagawa, Tokyo 142-0042, Japan
}

\begin{abstract}
Ariake Sound is a shallow, eutrophic estuarine system, located in the western part of Japan. We conducted field surveys and experiments in late autumn in 2002, 2003 and 2004 to clarify plankton community structure and trophic interactions in this system. A large photosynthetic dinoflagellate (Akashiwo sanguinea) was persistent and the dominant phytoplankton species in all years. Diatoms and other photosynthetic flagellates were relatively minor components of the assemblage. The growth of photosynthetic flagellates such as Prorocentrum micans and cryptophycean flagellates under nutrient-enriched conditions was almost balanced with the grazing losses caused by a microzooplankton population dominated by protozoans, rotifers and cyclopoid copepods. Thus, P. micans and cryptophycean flagellates could not propagate their populations in the field. Diatoms had high potential growth rates and were subjected to low grazing pressure by the micro- and mesozooplankton. However, diatom growth was severely limited by light in this highly turbid estuarine system, and light limitation probably prevented diatoms from becoming dominant. A. sanguinea was grazed on by the ciliate Tiarina fusus, but the growth rates of $A$. sanguinea exceeded grazing losses by $T$. fusus; other zooplankton species did not graze on this dinoflagellate effectively. A. sanguinea accumulated at the surface layer in the turbid water during daytime, and thus could utilize light effectively. Low grazing pressure by zooplankton and avoidance of light limitation seem to have led to the persistent dominance of $A$. sanguinea, even though the potential growth rate of this species is moderate to low.
\end{abstract}

KEY WORDS: Akashiwo sanguinea - Ariake Sound - Dilution experiments - Microzooplankton · Plankton community structure $\cdot$ Red tides $\cdot$ Rotifers $\cdot$ Tiarina fusus

\section{INTRODUCTION}

Shallow, semi-enclosed estuarine systems are vulnerable to eutrophication. Increases in nutrient loading often lead to increases in phytoplankton biomass, outbreaks of red tides, development of hypoxic/anoxic water and deterioration of the marine environment (Juhl \& Murell 2005 and references therein). Under these circumstances, understanding of the biological community structure and trophic interactions helps facilitate proper management of estuarine ecosystems.

Ariake Sound is a semi-enclosed, shallow and productive estuarine system in western Japan, with an area of $1700 \mathrm{~km}^{2}$ and an average water depth of $20 \mathrm{~m}$ (Fig. 1). The seaweed known as 'laver' (Porphyra yezoensis) is cultured intensively there, yielding an annual harvest of about 100000 metric tons and sales of 40 billion yen (Ministry of Agriculture, Forestry and Fisheries of Japan website: www.maff.go.jp/ ettitle.html). However, Ariake Sound is experiencing some problems. First, nutrient depletion of the ambient water due to persistent phytoplankton blooms during the autumn to winter period often reduces the quality of the laver cultured there; the economic damage reached 14 billion yen during the winter of 2000/2001. Second, intrusion of hypoxic water and red tides 


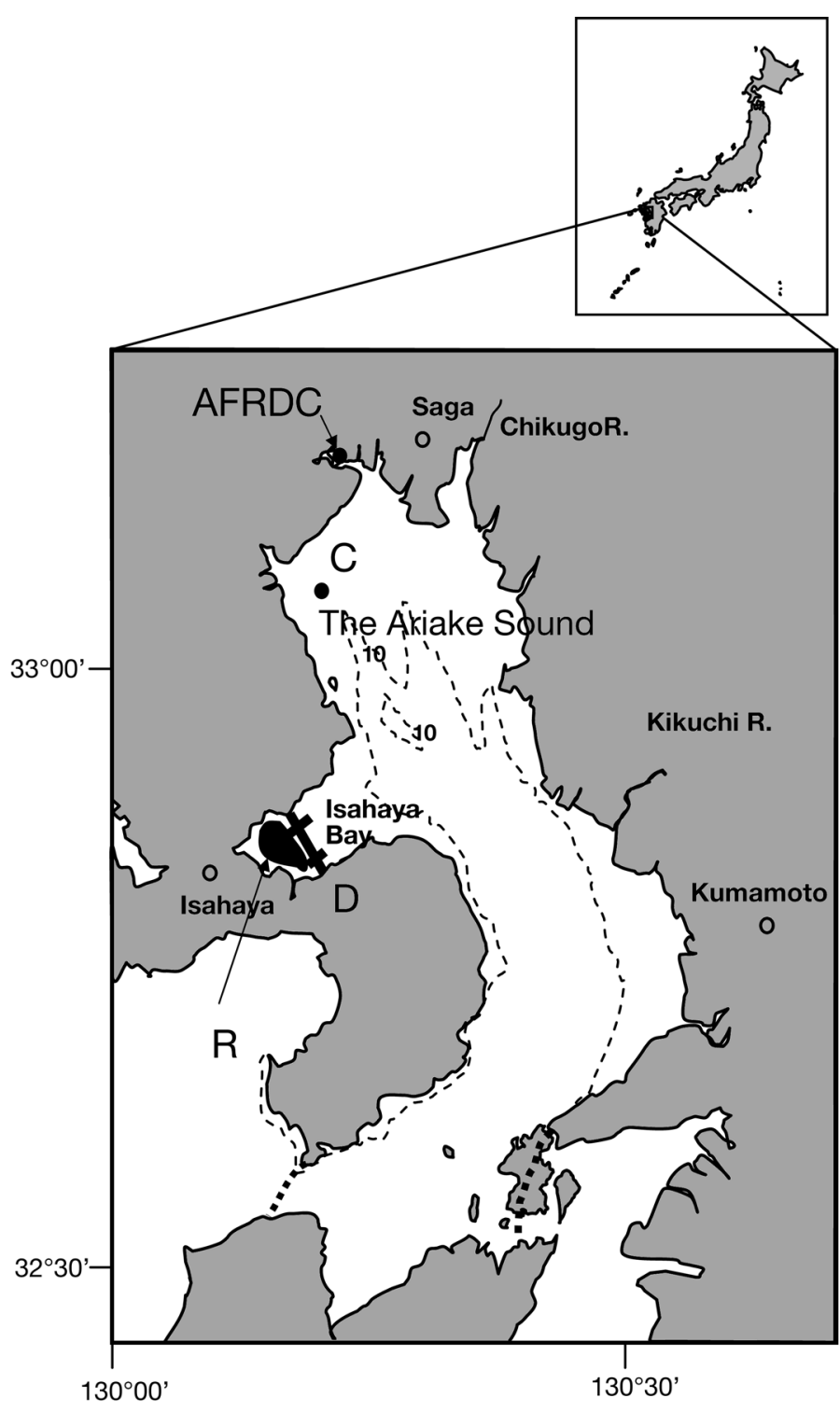

Fig. 1. Location of Ariake Sound, Japan. C: station for water sampling; D: dike for reclamation of Isahaya Bay; R: reclamation area; AFRDC: Ariake Fisheries Research and Development Center; thick dotted line: boundary of Ariake Sound; dashed line: $10 \mathrm{~m}$ isobath

during summer caused mass mortality of bivalves (Nakata 2004). In addition, a reclamation project underway since 1997, involving construction of a dike in Isahaya Bay (Fig. 1), has prompted heated public debate on the impact of the reclamation on fisheries and the ecosystem of Ariake Sound (Sato et al. 2001).

As part of efforts to assess the material cycling through food webs in Ariake Sound, the feeding activity of bivalves on phytoplankton as a function of environmental variables has been examined (Nakamura 2005, Nakamura et al. 2005). However, trophic inter- actions between phytoplankton and zooplankton populations in Ariake Sound have not yet been examined Although information on the abundance of phytoplankton and mesozooplankton species in Ariake Sound is now available (Kawamura et al. 1986, Islam et al. 2005), the trophic roles of microzooplankton therein, which could have a great impact on phytoplankton abundance and species composition (e.g. Nakamura et al.1995, 1996 and references therein), have not yet been assessed.

Dilution experiments were routinely used in previous studies on grazing of microzooplankton and growth of phytoplankton in natural populations (e.g. Landry \& Hasset 1982, Dolan et al. 2000, Umani \& Beran 2003). In most of these studies, growth and grazing loss of phytoplankton were assessed in terms of changes in chlorophyll a ( $\mathrm{chl}$ a) concentration, and the composition of phytoplankton species were often not considered. In addition, a trophic link between each microzooplankton component (such as ciliates, nauplii of copepods) and various phytoplankton species has only rarely been examined explicitly (exceptions: Umani \& Beran 2003 and references therein), making it difficult to clarify the trophic interactions in plankton populations.

In the present study, field monitorings and growth and grazing experiments (including dilution experiments) were conducted using natural plankton populations from Ariake Sound in the late autumn of 2002, 2003 and 2004, when outbreaks of persistent red tides were anticipated (see above). In these experiments, phytoplankton and (micro)zooplankton populations were enumerated microscopically. Objectives were: (1) to clarify the extent to which zooplankton grazing affects various phytoplankton species and (2) to establish the basis for understanding trophic dynamics and material cycling through plankton food webs in Ariake Sound.

\section{MATERIALS AND METHODS}

Field observations and sample treatments. Field surveys and sample collections were conducted at Stn $C\left(33^{\circ} 13^{\prime} \mathrm{N}, 130^{\circ} 12^{\prime} \mathrm{E}\right.$; Fig. 1) in November $(3,6$ and 6 sampling occasions for 2002, 2003 and 2004, respectively). Water depth at Stn $\mathrm{C}$ was $4 \mathrm{~m}$ at low tide, with a $\sim 5 \mathrm{~m}$ tidal amplitude. Sampling was conducted in the morning (08:20 to 09:20 h) irrespective of the tidal cycle. The Secchi depth, water temperature and salinity at 0 and $4 \mathrm{~m}$ were measured in situ. Light penetration was monitored in 2004 using a quantum sensor QSL-2100 (Biospherical Instruments). Water samples (2 l) for chemical and biological analyses were obtained from depths of 0 and $4 \mathrm{~m}$ using a plastic 
beaker and Van Dohn-type bottle, respectively. Mesozooplankton samples were collected in 2004 by oblique tows with open nets of $200 \mu \mathrm{m}$ mesh equipped with a flowmeter and a closed codend (1 l). Sampling volumes equaled several cubic meters. Samples were returned to the laboratory (Ariake Fisheries Research and Development Center, AFRDC) within $1 \mathrm{~h}$ and treated there.

Samples for nutrient analyses ( 100 ml) were filtered through GF/C filters, and the filtrates were stored at $-20^{\circ} \mathrm{C}$. Samples for chl a $(100$ to $200 \mathrm{ml})$ were filtered through GF/C filters. Chl a was measured fluorometrically with a Turner Designs Model 10 fluorometer (Trimmer et al. 1999).

Water samples $(40 \mathrm{ml})$ were fixed with glutaraldehyde (final conc. $1 \%$ ) for enumeration of some phytoplankton groups (cryptophycean flagellates and the dinoflagellate Prorocentrum micans) and to confirm autotrophy/heterotrophy of plankton cells by means of epifluorescence microscopy (see below). These samples were stored at $5^{\circ} \mathrm{C}$ until analysis (within $1 \mathrm{mo}$ ). The samples for enumeration of other phytoplankton and micro-protozooplankton were fixed with acid Lugol's (final conc. $2 \%$ ) and stored at $5^{\circ} \mathrm{C}$. Water samples $(1000 \mathrm{ml})$ for counting metazoan microzooplankton and the large heterotrophic dinoflagellate Noctiluca scintillans were concentrated through a $20 \mu \mathrm{m}$ sieve to a final volume of $50 \mathrm{ml}$, fixed with acid Lugol's (final conc. $2 \%$ ) and stored at $5^{\circ} \mathrm{C}$. Samples for mesozooplankton $(\sim 1000 \mathrm{ml})$ were fixed with neutralized formalin (final conc. $5 \%$ ) and stored at room temperature.

Plankton enumeration. Samples fixed with glutaraldehyde were stained with DAPI (final conc. $1 \mu \mathrm{g}$ $\mathrm{ml}^{-1}$ ) and 1 to $10 \mathrm{ml}$ (depending on cell concentration) of the sample was filtered through $0.8 \mu \mathrm{m}$ black Nuclepore filters (25 mm diameter). Filters were observed through an epifluorescence microscope under blue or UV light excitation (Nakamura et al. 1996). Cryptophycean flagellates (8 to $20 \mu \mathrm{m}$ cell length) with orange fluorescence were enumerated under $400 \times$ magnification. The autotrophic dinoflagellate Prorocentrum micans was identified based on cell shape, size and its unique U-shaped nucleus, and enumerated under $200 \times$ magnification. The whole field of each filter was examined for these enumerations.

The photosynthetic dinoflagellate Akashiwo sanguinea (previously Gymnodinium sanguineum; Daugbjerg et al. 2000), diatoms and protozooplankton were enumerated under an inverted microscope with appropriate magnification. For phytoplankton enumeration, 0.5 to $2 \mathrm{ml}$ of the seawater fixed with acid Lugol's was sampled in a counting chamber and counts were conducted by observing the whole field of the chamber. Ciliates were divided into 5 groups: naked small $(<40 \mu \mathrm{m})$, naked large $(>40 \mu \mathrm{m})$, small tintinnids
$(<40 \mu \mathrm{m})$, large tintinnids $(>40 \mu \mathrm{m})$ and Tiarina fusus $(\sim 100 \mu \mathrm{m})$. Samples were placed in a counting chamber of $2 \mathrm{ml}$ and usually counted for 10 to $20 \mathrm{ml}$. The heterotrophic dinoflagellate Katodinium glaucum $(40$ to $50 \mu \mathrm{m}$ ) was counted in the same way as ciliates. Heterotrophy of this species was assured by observations of the cells through the epifluorescence microscope.

For enumeration of metazoan microzooplankton, samples concentrated through a $20 \mu \mathrm{m}$ sieve were placed in a $2 \mathrm{ml}$ counting chamber and counted through an inverted microscope with magnification of 40 to $100 \times$ for 10 to $20 \mathrm{ml}$. Preliminary observations indicate that adults of the cyclopoid copepod Oithona davisae, which is abundant in the study area (see 'Results'), were not retained in the $200 \mu \mathrm{m}$ mesh net. Thus, copepodites and adults of this species were classified as microzooplankton.

Mesozooplankton were enumerated by observing $1 / 8$ to $1 / 2$ the volume of the samples under a dissecting microscope.

Dilution experiments. During the survey period in 2003 and 2004, experiments were conducted on 3 (Runs 1-3) and 2 (Runs 4 and 5) occasions, respectively. Following the monitoring and routine water sampling, experimental seawater was collected from the surface layer using a plastic beaker (5 l). A 201 carboy was gently filled with $200 \mu \mathrm{m}$ screened water to be used as whole water. Another 201 carboy was filled with seawater for the dilution medium (see below). Seawater samples were returned to the laboratory and treated there. Aliquots of 40 and $50 \mathrm{ml}$ from the $200 \mu \mathrm{m}$ screened water were fixed with glutaraldehyde and acid Lugol's, respectively, to estimate the initial abundance of phytoplankton and protozooplankton species. Of the $200 \mu \mathrm{m}$ screened water, 11 was also concentrated through a $20 \mu \mathrm{m}$ sieve to a final volume of $50 \mathrm{ml}$ and fixed with acid Lugol's for counting metazoan microzooplankton.

Replicate (essentially, triplicate) dilution treatments of $0.25,0.5$ and $1.0 \times$ natural seawater were prepared in glass bottles with final volumes of $1000 \mathrm{ml}$ replicate $^{-1}$. Water used for dilution was filtered through GF/C filters. Nutrients $\left[10 \mu \mathrm{M} \mathrm{NO}_{3}{ }^{-}, 1 \mu \mathrm{M} \mathrm{PO}_{4}{ }^{3-}\right.$ and $10 \mu \mathrm{M}$ $\mathrm{Si}(\mathrm{OH})_{4}$ ] were added to promote constant growth of phytoplankton. The experimental bottles were incubated on a rotating cultivator (0.5 rpm; RT-550 TAITEC) at $18^{\circ} \mathrm{C}$, with a light intensity of $\sim 120 \mu \mathrm{mol}$ photons $\mathrm{m}^{-2} \mathrm{~s}^{-1}$ and 10:14 h light:dark cycles for $24 \mathrm{~h}$. After incubations, samples were fixed as above for further enumeration. The abundance of each phytoplankton species was determined by counting at least 400 cells for solitary species or 3000 cells for the chainforming diatom Skeletonema costatum.

For each experiment, the phytoplankton growth rate under nutrient-enriched conditions $\left(\mu_{\mathrm{n}}\right.$ : potential 
growth rate) and phytoplankton mortality due to microzooplankton grazing $(g)$ were obtained by linear regression of the net growth rate $\left(k_{\mathrm{n}}\right)$ against the dilution factor $(D$, fraction of undiluted seawater; Landry \& Hassett 1982):

$$
\begin{gathered}
k_{\mathrm{n}}=(1 / T) \ln \left(N_{\mathrm{f}} / N_{0}\right) \\
k_{\mathrm{n}}=\mu_{\mathrm{n}}-g D
\end{gathered}
$$

where $N_{0}$ and $N_{\mathrm{f}}$ are the initial and final cell concentrations, and $T$ is the incubation period. When the regressions were non-significant, the $g$-value was set to zero and $\mu_{\mathrm{n}}$ was calculated as the mean of all treatments (Juhl \& Murrell 2005).

Grazing by mesozooplankton. Experiments were conducted on 2 occasions in 2004. Unscreened and $200 \mu \mathrm{m}$ screened surface seawater samples were taken from Stn C (20 l each) and brought back to the laboratory. The unscreened water was passed through a $200 \mu \mathrm{m}$ mesh sieve, and the $>200 \mu \mathrm{m}$ fraction was concentrated to $400 \mathrm{ml}$. Then, $100 \mathrm{ml}$ of the concentrated fraction was fixed with formaldehyde (5\% final conc.) for enumeration of mesozooplankton. The remaining $300 \mathrm{ml}$ of the concentrated fraction was added to $3000 \mathrm{ml}$ of $200 \mu \mathrm{m}$ screened seawater. By doing this, mesozooplankton abundance was enriched to 5 times that in the original seawater. The water was poured into $2(1000 \mathrm{ml})$ glass bottles, and the remaining $1300 \mathrm{ml}$ was used for estimation of initial phytoplankton and microzooplankton abundance. Control bottles without mesozooplankton were also prepared in duplicate. These bottles were enriched with nutrients and incubated as in the dilution experiments. After incubation, samples were fixed as above and $k_{\mathrm{n}}$-values were calculated (Eq. 1).

In situ growth experiments. In order to estimate the degree of light limitation on the growth of diatoms, in situ growth experiments were conducted on 2 occasions at Stn C in 2004. Surface seawater (200 $\mu \mathrm{m}$ screened; prepared on board) was filled into 6 glass bottles (1200 ml) and enriched with nutrients as above. The bottles were filled to be free of air spaces or bubbles. A $50 \mathrm{ml}$ aliquot of $200 \mu \mathrm{m}$ screened seawater was fixed with acid Lugol's to estimate the initial concentration of phytoplankton cells. The bottles were suspended from a buoy at depths of $0.5,2$ and $4 \mathrm{~m}$, in duplicate at each depth, for $24 \mathrm{~h}$. The bottles were then retrieved, and the samples were fixed with Lugol's. Following enumeration, $k_{\mathrm{n}}$-values were calculated (Eq. 1).

Grazing by rotifers. During the survey period of 2004, grazing by rotifers was examined on 2 occasions. Rotifers were isolated in the laboratory from the surface seawater of Stn C using a micropipette under a dissecting microscope. About 200 individuals were isolated into seawater of the $<63 \mu \mathrm{m}$ fraction $(100 \mathrm{ml}$, in a beaker) and preconditioned overnight at $18^{\circ} \mathrm{C}$. On the next day, 80 individuals in the preconditioning culture were isolated again to $<63 \mu \mathrm{m}$ seawater, which was obtained on the day of re-isolation from Stn C, in a $50 \mathrm{ml}$ plastic tube. The tube was kept free of air space by the use of parafilm. Aliquots of 40 and $50 \mathrm{ml}$ of the $<63 \mu \mathrm{m}$ seawater were also fixed with glutaraldehyde and acid Lugol's, respectively, for enumeration of phytoplankton cells. Unfortunately, since about half of the rotifers became inactive or died during the preconditioning, we could not conduct the experiments in duplicate. A control bottle with no rotifers was also prepared. The tubes were set in the rotating cultivator (0.5 rpm; RT-5, TAITEC) and incubated at $18^{\circ} \mathrm{C}$ for $15 \mathrm{~h}$ under a dim light. Following incubation, samples were fixed with glutaraldehyde $(20 \mathrm{ml})$ and acid Lugol's (30 ml). Following enumeration, $k_{\mathrm{n}}$-values were calculated (Eq. 1).

\section{RESULTS}

\section{Field observations}

Physical and chemical environment

Physical and chemical variables at Stn $\mathrm{C}$ are summarized in Table 1. Waters were turbid throughout the survey period, and the concentration of inorganic suspended matter at the surface sometimes exceeded $15 \mathrm{mg} \mathrm{l}^{-1}$ (data not shown in Table 1). When a heavy red tide by the dinoflagellate Akashiwo sanguinea occurred on 9 November 2004, nitrogenous nutrients $\left(\mathrm{NO}_{3}{ }^{-}+\mathrm{NO}_{2}{ }^{-}+\mathrm{NH}_{4}{ }^{+}\right)$were almost depleted $(1.2 \mu \mathrm{M})$, but $\mathrm{PO}_{4}{ }^{3-}$ and $\mathrm{Si}(\mathrm{OH})_{4}$ remained sufficiently replete, with concentrations of 0.5 and $68.6 \mu \mathrm{M}$, respectively.

\section{Chlorophyll and phytoplankton}

Annual changes in biological variables are summarized in Table 2. Chl a was in the range of 3.8 to $94.1 \mu \mathrm{g} \mathrm{l}^{-1}$. The photosynthetic dinoflagellate Akashiwo sanguinea (cell length $\sim 80 \mu \mathrm{m}$ ) was abundant throughout the survey period, and its abundance at the surface greatly exceeded that at $4 \mathrm{~m}$, indicating strong and positive phototaxis (Park et al. 2002a). There was a strong positive correlation between the abundance of $A$. sanguinea $\left(x\right.$ : cells $\left.\mathrm{ml}^{-1}\right)$ and chl $a$ concentrations $\left(y: \mu \mathrm{g} \mathrm{l}^{-1}\right)\left(\mathrm{r}^{2}=0.838, \mathrm{n}=29, \mathrm{p}<0.001\right.$; $y=0.11 x+7.2)$, indicating that the abundance of $A$. sanguinea was the determinant factor of phytoplankton biomass ( $\mathrm{chl} \mathrm{a}$ ) in Ariake Sound. In addition, the $y$-intercept of the above regression $\left(7.2 \mu \mathrm{g} \mathrm{chl} \mathrm{a} \mathrm{l}^{-1}\right)$ shows that the contributions of other phytoplankton 
species to chl a concentrations were $<10 \mu \mathrm{g} \mathrm{l}^{-1}$. Abundant phytoplankton species other than $A$. sanguinea were the diatoms Cerataulina pelagica (cell length $\sim 30 \mu \mathrm{m} ;$ 2002), Chaetoceros debilis (cell length $\sim 15 \mu \mathrm{m}$; solitary or 2 cells colony ${ }^{-1}$; 2003) and Skeletonema costatum (cell length $\sim 10 \mu \mathrm{m} ; 4$ to 20 cells chain $^{-1}$; 2003 and 2004), as well as the dinoflagellate Prorocentrum micans (cell length $\sim 40 \mu m_{i}$ 2004). Cryptophycean flagellates with a size range of 8 to $20 \mu \mathrm{m}$ were also present at an abundance of 30 to 730 cells $\mathrm{ml}^{-1}$ throughout the survey period. Picocyanobacteria and autotrophic nanoflagellates with sizes of 2 to $8 \mu \mathrm{m}$ were also present, but were minor throughout the survey period (data not shown).

\section{Protozooplankton}

The heterotrophic dinoflagellate Katodinium glaucum (cell length $\sim 40 \mu \mathrm{m}$ ) was abundant in 2002 and 2003 (11 to 285 cells $\mathrm{ml}^{-1}$ at the surface layer; Table $2)$. Prominent ciliate species were the tintinnid Favella taraikaensis $(\sim 80 \mu \mathrm{m})$ and the naked oligotrichid Strombidium strobilum $(\sim 80 \mu \mathrm{m})$, which were present at concentrations of 0.1 to 1 cells $\mathrm{ml}^{-1}$. In 2003, the large prostomatid ciliate Tiarina fusus (cell length $\sim 100 \mu \mathrm{m}$ ) was also abundant (2.5 to 9 cells $\mathrm{ml}^{-1}$ at $0 \mathrm{~m}$ ), and cells that contained large particles (several 10s of $\mu \mathrm{m}$ in size) were occasionally observed. These particles showed red autofluorescence under blue light excitation through the epifluorescence microscope. On one occasion, nucleus-like material with the size of Akashiwo sanguinea's nucleus was observed in an apparently swallowed particle inside a cell of $T$. fusus.
Metazoan microzooplankton

Rotifers (Synchaeta spp.; $150 \mu \mathrm{m}$ in length) were abundant (36 to 540 ind. $\mathrm{l}^{-1}$ at $0 \mathrm{~m}$ ) in 2002 and 2004. Microscopical observations of the mouthpart morphology indicated that rotifers in 2004 were dominated by 1 species of Synchaeta. Nauplii of copepods were abundant (9 to 1370 ind. $\mathrm{l}^{-1}$; usually $>100$ ind. $\mathrm{l}^{-1}$ ) throughout the survey period and most of them belonged to the cyclopoids. The abundance of adults/ copepodid stages of the cyclopoid copepod Oithona davisae varied greatly, ranging from 3 to 603 ind. $\mathrm{l}^{-1}$.

\section{Mesozooplankton}

Abundance of the large heterotrophic dinoflagellate Noctiluca scintillans ( $400 \mu \mathrm{m}$ in cell diameter) was in the range of $<2$ to 128 cells $1^{-1}$ during the survey period. Metazoan mesozooplankton in 2004 were mainly composed of the calanoid copepod Paracalanus parvus and the appendicularian Oikopleura dioica (Table 2).

\section{Experiments using natural plankton populations}

Dilution experiments

Results are summarized in Tables $3 \& 4$ and Fig. 2. In addition to the experiments listed in the tables, we tried to conduct dilution experiments on 9 November 2004, when a dense red tide by Akashiwo sanguinea occurred (2260 cells ml $\mathrm{m}^{-1}$ at the surface layer). However, as mass mortality of $A$. sanguinea in the experi-

Table 1. Physical and chemical environment during the survey period. nd: not determined

\begin{tabular}{|c|c|c|c|c|}
\hline & Depth (m) & 13-18 Nov 2002 & 11-18 Nov 2003 & 9-16 Nov 2004 \\
\hline Water temperature $\left({ }^{\circ} \mathrm{C}\right)$ & $\begin{array}{l}0 \\
4\end{array}$ & $\begin{array}{l}12.6-14.1 \\
14.3-15.0\end{array}$ & $\begin{array}{l}14.0-19.5 \\
17.0-19.5\end{array}$ & $\begin{array}{l}18.5-20.0 \\
18.5-20.5\end{array}$ \\
\hline Salinity (psu) & $\begin{array}{l}0 \\
4\end{array}$ & $\begin{array}{l}27.4-30.0 \\
30.2-30.3\end{array}$ & $\begin{array}{l}26.6-28.4 \\
28.6-29.2\end{array}$ & $\begin{array}{l}26.5-28.7 \\
27.7-29.0\end{array}$ \\
\hline Secchi depth $(\mathrm{m})$ & & $1.5-2.3$ & $0.7-1.2$ & $0.5-1.3$ \\
\hline Light extinction coefficient $\left(\mathrm{m}^{-1}\right)$ & & nd & nd & $0.73-2.22$ \\
\hline $\mathrm{NO}_{3}^{-}+\mathrm{NO}_{2}^{-}(\mu \mathrm{M})$ & $\begin{array}{l}0 \\
4\end{array}$ & $\begin{array}{l}0.9-7.4 \\
0.9-4.7\end{array}$ & $\begin{array}{l}8.1-19.7 \\
3.7-11.9\end{array}$ & $\begin{array}{r}0.3-7.4 \\
4.8-7.6\end{array}$ \\
\hline $\mathrm{NH}_{4}{ }^{+}(\mu \mathrm{M})$ & $\begin{array}{l}0 \\
4\end{array}$ & $\begin{array}{l}0.6-0.9 \\
1.0-3.3\end{array}$ & $\begin{array}{l}2.1-7.1 \\
1.6-6.9\end{array}$ & $\begin{array}{l}0.2-0.5 \\
1.2-2.7\end{array}$ \\
\hline $\mathrm{PO}_{4}{ }^{3-}(\mu \mathrm{M})$ & $\begin{array}{l}0 \\
4\end{array}$ & $\begin{array}{l}0.7-1.3 \\
0.9-1.0\end{array}$ & $\begin{array}{l}1.7-2.6 \\
1.3-1.8\end{array}$ & $\begin{array}{l}0.5-0.9 \\
0.7-1.0\end{array}$ \\
\hline $\mathrm{Si}(\mathrm{OH})_{4}(\mu \mathrm{M})$ & $\begin{array}{l}0 \\
4\end{array}$ & $\begin{array}{l}73.0-100.1 \\
76.6-88.2\end{array}$ & $\begin{array}{l}84.6-121.3 \\
66.9-87.3\end{array}$ & $\begin{array}{l}49.3-69.7 \\
38.4-66.5\end{array}$ \\
\hline
\end{tabular}


Table 2. Annual changes in biological variables at Stn $\mathrm{C}$ during the survey period. nd: not determined

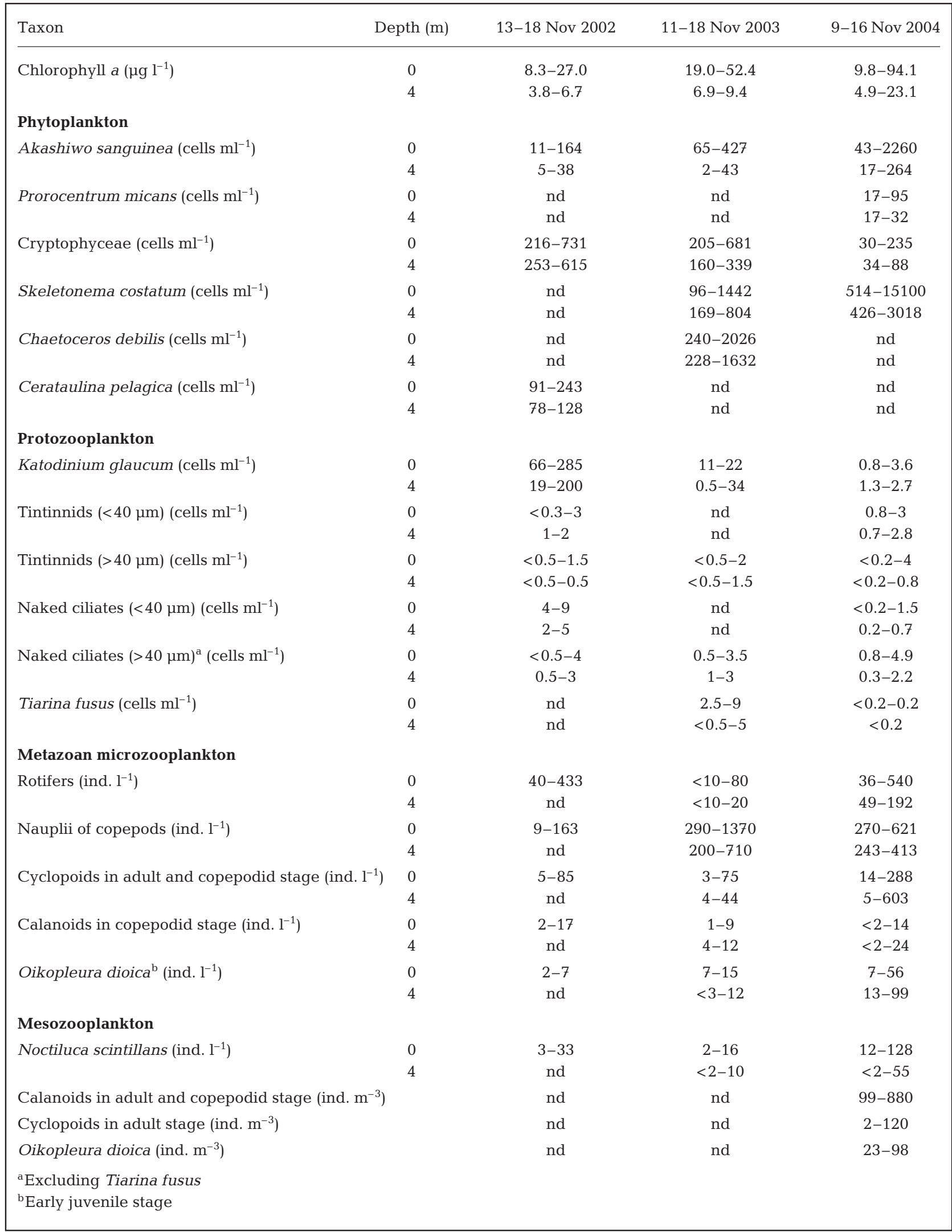


Table 3. Initial conditions of dilution experiments. nd: not determined

\begin{tabular}{|c|c|c|c|c|c|}
\hline Taxon & $\begin{array}{c}\text { Run } 1 \\
11 \text { Nov } 2003\end{array}$ & $\begin{array}{c}\text { Run } 2 \\
14 \text { Nov } 2003\end{array}$ & $\begin{array}{c}\text { Run } 3 \\
17 \text { Nov } 2003\end{array}$ & $\begin{array}{c}\text { Run } 4 \\
12 \text { Nov } 2004\end{array}$ & $\begin{array}{c}\text { Run } 5 \\
15 \text { Nov } 2004\end{array}$ \\
\hline \multicolumn{6}{|l|}{ Phytoplankton } \\
\hline Akashiwo sanguinea (cells ml $\mathrm{m}^{-1}$ ) & 85 & 127 & 72 & 49 & 60 \\
\hline Prorocentrum micans (cells $\mathrm{ml}^{-1}$ ) & nd & nd & nd & 42 & 31 \\
\hline Cryptophyceae (cells ml ${ }^{-1}$ ) & nd & nd & nd & 185 & 147 \\
\hline Skeletonema costatum (cells $\mathrm{ml}^{-1}$ ) & 117 & 355 & 355 & 377 & 720 \\
\hline Chaetoceros debilis (cells $\mathrm{ml}^{-1}$ ) & 391 & 660 & 1868 & nd & nd \\
\hline \multicolumn{6}{|l|}{ Protozooplankton } \\
\hline Katodinium glaucum (cells ml ${ }^{-1}$ ) & 19 & 15 & 11 & 2.8 & 3.6 \\
\hline Tintinnids $(<40 \mu \mathrm{m})\left(\right.$ cells $\left.\mathrm{ml}^{-1}\right)$ & nd & nd & nd & 3.0 & 2.2 \\
\hline Tintinnids $(>40 \mu \mathrm{m})\left(\right.$ cells $\left.\mathrm{ml}^{-1}\right)$ & 1.2 & 2.1 & 1.4 & 0.4 & 0 \\
\hline Naked ciliates $(<40 \mu \mathrm{m})\left(\right.$ cells $\left.\mathrm{ml}^{-1}\right)$ & nd & nd & nd & 1.2 & 0.5 \\
\hline Naked ciliates $(>40 \mu \mathrm{m})^{\mathrm{a}}\left(\right.$ cells $\left.\mathrm{ml}^{-1}\right)$ & 2.5 & 0.6 & 3.7 & 4.9 & 3.9 \\
\hline Tiarina fusus (cells $\mathrm{ml}^{-1}$ ) & 9.2 & 7.8 & 4.0 & $<0.1$ & $<0.1$ \\
\hline \multicolumn{6}{|l|}{ Metazoan microzooplankton } \\
\hline Rotifers (ind. $\mathrm{l}^{-1}$ ) & 50 & 78 & 6 & 536 & 175 \\
\hline Nauplii of copepods (ind. $1^{-1}$ ) & 1370 & 760 & 1080 & 576 & 357 \\
\hline Cyclopoids (ind. $\mathrm{l}^{-1}$ ) & 75 & 9 & 18 & 24 & 14 \\
\hline Calanoids in copepodid stage (ind. $\mathrm{l}^{-1}$ ) & 3 & 2 & 1 & $<3$ & $<3$ \\
\hline Oikopleura dioica ${ }^{\mathrm{b}}$ (ind. $\mathrm{l}^{-1}$ ) & 7 & 7 & 15 & 48 & 21 \\
\hline $\begin{array}{l}{ }^{\mathrm{a}} \text { Excluding Tiarina fusus } \\
{ }^{\mathrm{b}} \text { Early juvenile stage }\end{array}$ & & & & & \\
\hline
\end{tabular}

mental seawater occurred during the transportation from Stn C to the laboratory (cause unknown), these experiments were cancelled. The potential growth rates $\left(\mu_{\mathrm{n}}\right)$ for $A$. sanguinea in 2003 and 2004 were in the range of 0.13 to $0.52 \mathrm{~d}^{-1}$ and were higher in 2003 than in 2004. Grazing of $A$. sanguinea by microzooplankton was significant in 2003 ( $g=0.17$ to $0.36 \mathrm{~d}^{-1}$; $\mathrm{p}<0.05$ ), but not significant in 2004 .

$\mu_{\mathrm{n}}$ for diatoms (Skeletonema costatum and Chaetoceros debilis) were high ( $>1 \mathrm{~d}^{-1}$; Table 4$)$ in both years. Grazing of diatoms by microzooplankton was not significant except for Run $4\left(g=0.22 \mathrm{~d}^{-1} ; \mathrm{p}<0.05 ; 2004\right)$.

Both Prorocentrum micans and cryptophycean flagellates showed moderate $\mu_{\mathrm{n}}\left(\sim 0.5 \mathrm{~d}^{-1}\right)$ and $g\left(0.4\right.$ to $\left.0.8 \mathrm{~d}^{-1}\right)$. The growth rate of Tiarina fusus, which was measured on the basis of changes in abundance in undiluted bottles, was in the range of 0.32 to $0.56 \mathrm{~d}^{-1}$, and was comparable to those obtained by Jeong et al. (2002).

\section{Other experiments}

In mesozooplankton grazing experiments, $k_{\mathrm{n}}$ of each phytoplankton species in the experimental bottles (i.e. mesozooplankton enriched) was consistently lower than in the control bottles (Table 5). However, the difference in $k_{\mathrm{n}}$ between the control and experimental bottles was small $\left(\leq 0.1 \mathrm{~d}^{-1}\right)$.

In the in situ growth experiments, Skeletonema costatum grew rapidly $\left(>1 \mathrm{~d}^{-1}\right)$ at a depth of $0.5 \mathrm{~m}$
Table 4. Summary of growth rates under nutrient-replete conditions $\left(\mu_{\mathrm{n}}\right.$ potential growth rates), grazing parameters $(g)$ and the $r^{2}$ of the individual regressions of net growth versus dilution for the various phytoplankton species. * Statistically significant at $\mathrm{p}<0.05$

\begin{tabular}{|c|c|c|c|}
\hline Taxon & $\mu_{\mathrm{n}}\left(\mathrm{d}^{-1}\right)$ & $g\left(\mathrm{~d}^{-1}\right)$ & $r^{2}$ \\
\hline \multicolumn{4}{|l|}{ Run 1, 11 Nov 2003} \\
\hline Akashiwo sanguinea & 0.25 & 0.17 & $0.92^{*}$ \\
\hline Skeletonema costatum & 1.51 & 0 & 0.10 \\
\hline Chaetoceros debilis & 1.13 & 0 & 0.10 \\
\hline Tiarina fusus & \multicolumn{3}{|l|}{$0.41(\mathrm{SD}=0.03)$} \\
\hline \multicolumn{4}{|l|}{ Run 2, 14 Nov 2003} \\
\hline Akashiwo sanguinea & 0.52 & 0.33 & $0.83^{*}$ \\
\hline Skeletonema costatum & 1.66 & 0 & 0.03 \\
\hline Chaetoceros debilis & 1.33 & 0 & 0.00 \\
\hline Tiarina fusus & \multicolumn{3}{|l|}{$0.56(\mathrm{SD}=0.21)$} \\
\hline \multicolumn{4}{|l|}{ Run 3, 17 Nov 2003} \\
\hline Akashiwo sanguinea & 0.45 & 0.36 & $0.88^{*}$ \\
\hline Skeletonema costatum & 1.39 & 0 & 0.00 \\
\hline Chaetoceros debilis & 1.18 & 0 & 0.06 \\
\hline Tiarina fusus & \multicolumn{3}{|l|}{$0.32(\mathrm{SD}=0.11)$} \\
\hline \multicolumn{4}{|l|}{ Run 4, 12 Nov 2004} \\
\hline Akashiwo sanguinea & 0.17 & 0 & 0.34 \\
\hline Skeletonema costatum & 1.25 & 0.22 & $0.64^{*}$ \\
\hline Prorocentrum micans & 0.43 & 0.37 & $0.74^{*}$ \\
\hline Cryptophyceae & 0.41 & 0.67 & $0.74^{*}$ \\
\hline \multicolumn{4}{|l|}{ Run 5, 15 Nov 2004} \\
\hline Akashiwo sanguinea & 0.13 & 0 & 0.46 \\
\hline Skeletonema costatum & 1.29 & 0 & 0.43 \\
\hline Prorocentrum micans & 0.48 & 0.42 & $0.62^{*}$ \\
\hline Cryptophyceae & 0.51 & 0.76 & $0.84^{*}$ \\
\hline
\end{tabular}


(Fig. 3). However, the growth rates were greatly retarded $\left(<0.2 \mathrm{~d}^{-1}\right)$ at depths of $\geq 2 \mathrm{~m}$.

In the rotifer grazing experiments, $k_{\mathrm{n}}$ of Prorocentrum micans and cryptophycean flagellates were much lower in experimental bottles (i.e. rotifers were enriched) than in control bottles (Fig. 4). In contrast, rotifers did not seem to feed on Skeletonema costatum and Akashiwo sanguinea, as $k_{\mathrm{n}}$ of these species in the

(A) Akashiwo sanguinea (2003)

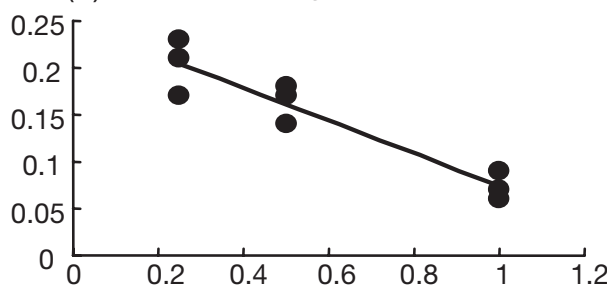

(B) Akashiwo sanguinea (2004)
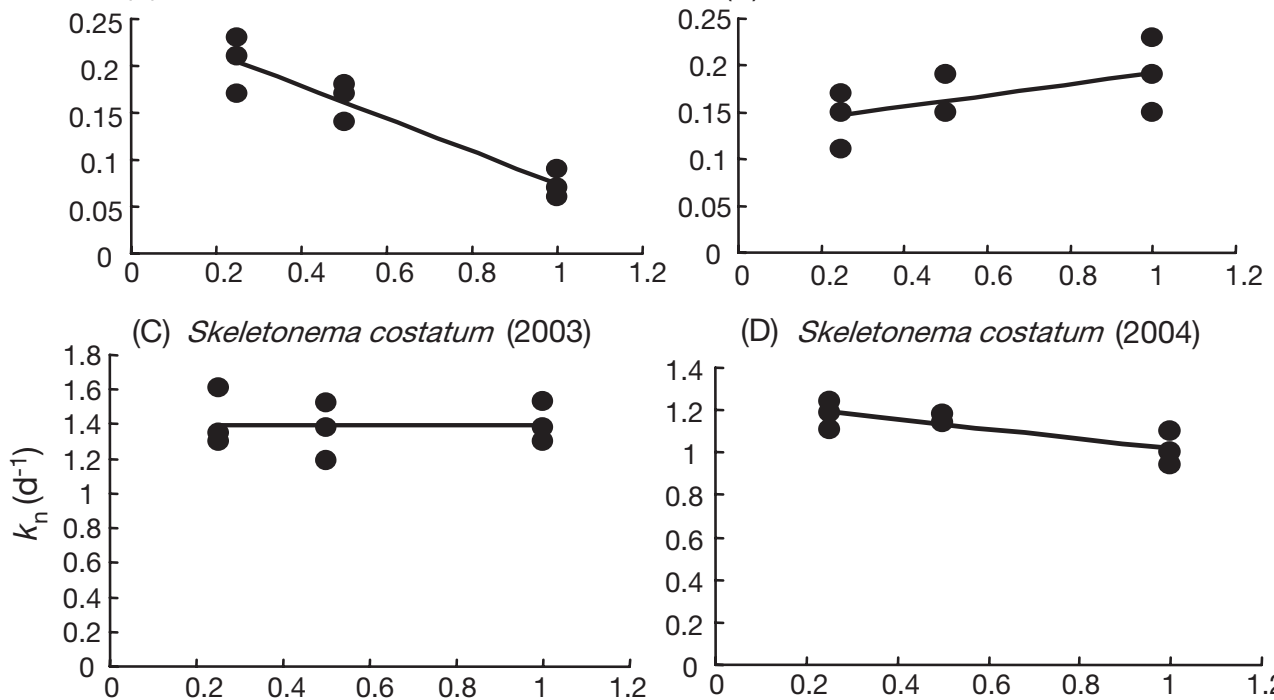

(D) Skeletonema costatum (2004)

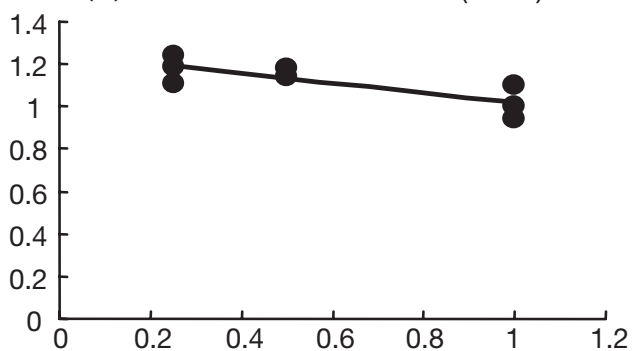

(E) Prorocentrum micans (2004)

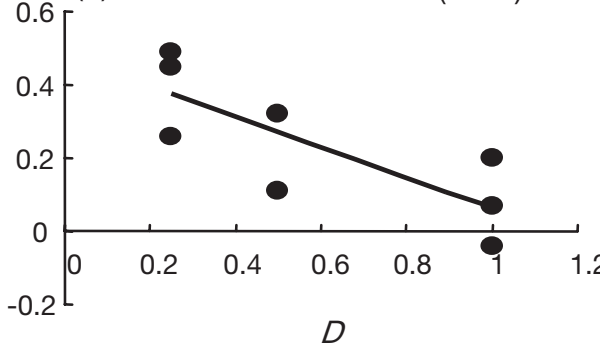

(F) Cryptophycean flagellates (2004)

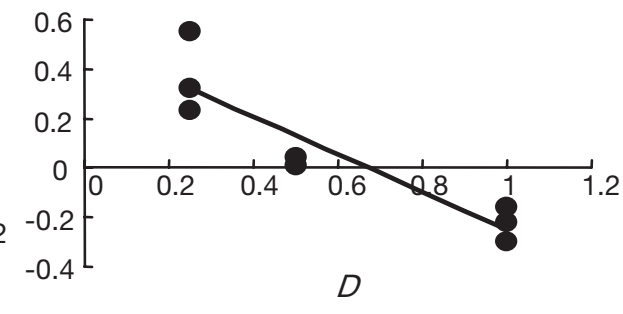

Fig. 2. Dilution experiments. Net growth rate $\left(k_{\mathrm{n}}\right)$ of phytoplankton species plotted against the fraction of unfiltered seawater $(D)$. Lines were least-squares fit by linear regression. (A) Akashiwo sanguinea in Run 1 (2003), (B) A. sanguinea in Run 4 (2004), (C) Skeletonema costatum in Run 3 (2003), (D) S. costatum in Run 4 (2004), (E) Prorocentrum micans in Run 5 (2004) and (F) cryptophycean flagellates in Run 5 (2004)

Table 5. Observed net growth rates of phytoplankton species in the seawater with mesozooplankton enrichment (Experiment) and without enrichment (Control). Initial abundance of mesozooplankton in the experiments is shown; see Table 3 for initial abundance of microzooplankton

\begin{tabular}{|c|c|c|c|}
\hline Taxon & $\begin{array}{l}\text { Enrichment } \\
\text { status }\end{array}$ & $\begin{array}{c}\text { Run } 1 \\
12 \text { Nov } 2004\end{array}$ & $\begin{array}{c}\text { Run } 2 \\
15 \text { Nov } 2004\end{array}$ \\
\hline \multicolumn{4}{|c|}{ Net growth rate $\left(\mathrm{d}^{-1}\right)$ (average \pm range of duplicate experiments) } \\
\hline \multirow[t]{2}{*}{ Akashiwo sanguinea } & Experiment & $0.19 \pm 0.03$ & $0.15 \pm 0.15$ \\
\hline & Control & $0.24 \pm 0.06$ & $0.23 \pm 0.08$ \\
\hline \multirow[t]{2}{*}{ Skeletonema costatum } & Experiment & $0.79 \pm 0.02$ & $0.92 \pm 0.05$ \\
\hline & Control & $0.89 \pm 0.03$ & $1.05 \pm 0.03$ \\
\hline \multirow[t]{2}{*}{ Prorocentrum micans } & Experiment & $0.11 \pm 0.01$ & $-0.08 \pm 0.18$ \\
\hline & Control & $0.12 \pm 0.08$ & $-0.04 \pm 0.06$ \\
\hline \multicolumn{4}{|c|}{ Initial abundance of mesozooplankton (ind. $\mathrm{l}^{-1}$ ) } \\
\hline \multicolumn{2}{|l|}{ Noctiluca scintillans } & 138 & 154 \\
\hline \multicolumn{2}{|l|}{ Oikopleura dioica } & 1 & $<1$ \\
\hline \multicolumn{2}{|l|}{ Paracalanus parvus } & 2 & 2 \\
\hline
\end{tabular}


control and experimental bottles were comparable. The clearance rates (CR) of rotifers were also estimated using Frost's (1972) equation. As half of the rotifers became inactive or died during the acclimation
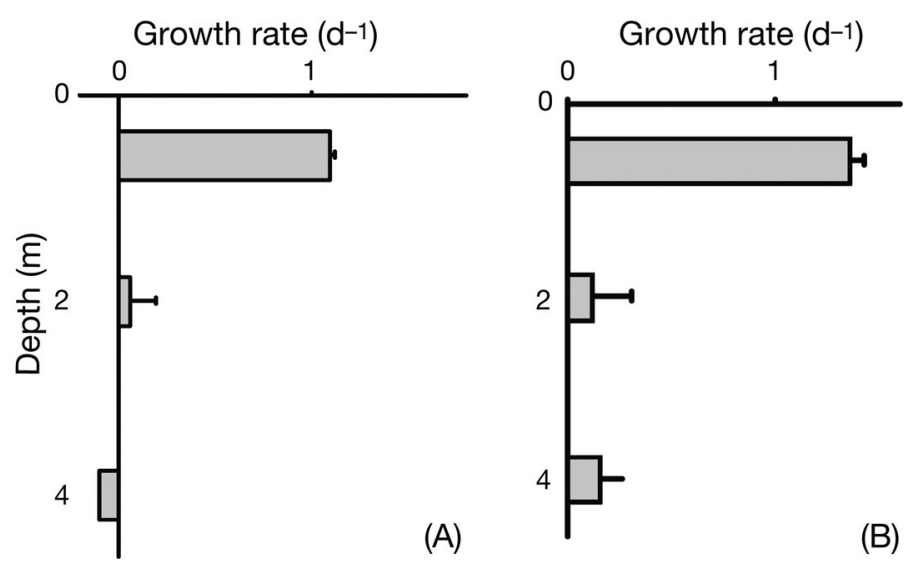

Fig. 3. Skeletonema costatum. In situ growth experiments. Net growth rate as a function of water depth for (A) Run 1 (started on 12 November 2004) and (B) Run 2 (started on 15 November 2004). Error bars indicate the range of duplicate experiments

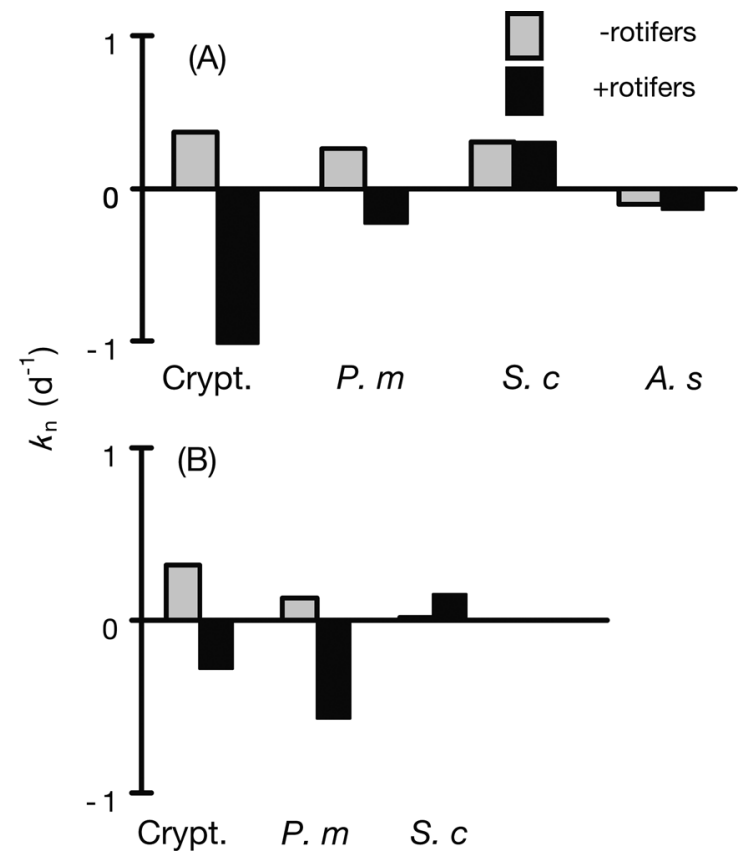

Fig. 4. Rotifer grazing experiments. Net growth rates of phytoplankton species in experimental (rotifers enriched; filled bars) and control (not enriched; hatched bars) bottles for (A) Run 1 (started on 13 November 2004) and (B) Run 2 (started on 16 November 2004). Crypt.: cryptophycean flagellates; P. m: Prorocentrum micans; S. c: Skeletonema costatum; A. s: Akashiwo sanguinea. In Run 2, the net growth rate of $A$. sanguinea was not obtained due to heavy mortality of the dinoflagellate in both control and experimental bottles period, the remaining animals used in the experiments may have been in 'unhealthy' conditions; CR values might be underestimated. Under these constraints, CRs on P. micans were 0.016 and $0.023 \mathrm{ml}$ ind.$^{-1} \mathrm{~h}^{-1}$ in Run 1 and Run 2, respectively. CRs for cryptophycean flagellates were 0.052 and $0.020 \mathrm{ml}$ ind..$^{-1} \mathrm{~h}^{-1}$ in Run 1 and Run 2, respectively.

\section{DISCUSSION}

Our field observations carried out over 3 years indicate that the plankton community structure of northern Ariake Sound in autumn was characterized by (1) persistent dominance of the large photosynthetic dinoflagellate Akashiwo sanguinea and (2) high abundance of microzooplankton, including protozoans, rotifers and cyclopoid copepods. In order to clarify how such a community structure was maintained, growth of phytoplankton species and grazing of zooplankton on phytoplankton species are discussed.

\section{Akashiwo sanguinea and its predators}

Dilution experiments were conducted at $18^{\circ} \mathrm{C}$ under light-sufficient, nutrient-replete conditions in 2003 and 2004. Thus, the growth rates of each phytoplankton species in both years were expected to be similar. However, the potential growth rates of $A$. sanguinea in dilution experiments in 2003 were much higher than those in 2004 (Table 4). Although not conclusive, one possible explanation for this variation is infection by parasites (Coats et al. 1996); in our epifluorescence microscope observations of $A$. sanguinea cells, cells containing parasite-like particles were often found in the 2004 samples (we performed no quantitative enumeration), and parasitic infection prevented cell division of $A$. sanguinea in one study (Park et al. 2002b). The variations in growth rate could also be explained in terms of mixotrophy of A. sanguinea (Bockstahler \& Coats 1993); changes in prey quality and quantity between experiments may have induced such variations. However, we have not observed food-vacuole-like structure in A. sanguinea cells, so mixotrophy probably does not explain the variations in growth rates. Another explanation is that the variations in growth rate were caused by the effects of high $\mathrm{pH}$ (Pedersen \& Hansen 2003). As our dilution experiments were conducted at high chl a levels, pH values were anticipated to be high ( 9); thus, growth rates might have been affected by a slight change in $\mathrm{pH}$. Unfortunately, pH was not monitored in the present study, and its effects should be considered in future studies. 
Although highly variable, $\mu_{n}$ of $A$. sanguinea never exceeded $0.7 \mathrm{~d}^{-1}\left(1\right.$ division $\left.\mathrm{d}^{-1}\right)$; this was consistent with previous results that showed the growth rates of photosynthetic dinoflagellates were usually $<0.7 \mathrm{~d}^{-1}$ (Loeblich 1967).

Akashiwo sanguinea was grazed by microzooplankton in the 2003 dilution experiments, but not in 2004 (Table 4). Tiarina fusus, which was scarce in 2004, was abundant in 2003 (Table 3), and food vacuoles apparently originating from $A$. sanguinea were occasionally observed in the ciliate. In addition, $T$. fusus is known to graze on phytoplankton species with sizes similar to their own (Jeong et al. 2002). These results indicate that $T$. fusus grazed on $A$. sanguinea. In contrast, the microzooplankton groups abundant in 2004 (such as rotifers, copepodites/adults of Oithona davisae and nauplii of copepods; Table 3) were not effective grazers on $A$. sanguinea; the results of the rotifer grazing experiments were consistent with this, and showed no positive grazing on $A$. sanguinea (Fig. 4). Although O. davisae is known to feed on microflagellates (Uchima \& Hirano 1986), this copepod may have avoided feeding on A. sanguinea. Protozoans such as Katodinium glaucum and ciliates (except for T. fusus) were probably too small to graze on A. sanguinea.

Assuming that the grazing loss of Akashiwo sanguinea in dilution experiments in 2003 were attributed to grazing by Tiarina fusus alone, CRs of the ciliate on A. sanguineum can be approximated as:

$$
\mathrm{CR}=g / N_{\mathrm{Z}}
$$

where $N_{\mathrm{Z}}$ is the average concentration of $T$. fusus during incubation. Values of $g$ and $N_{\mathrm{Z}}$ were $\sim 0.3 \mathrm{~d}^{-1}$ and $\sim 8$ cells $\mathrm{ml}^{-1}$ in the 2003 experiments, respectively, resulting in CR values of $\sim 2 \mu \mathrm{l}$ ind. ${ }^{-1} \mathrm{~h}^{-1}$. This is comparable to the value reported for $T$. fusus in a previous study (Jeong et al. 2002).

\section{Prorocentrum micans/cryptophycean flagellates}

Although mixotrophic growth was indicated for these phytoplankton groups (e.g. Jeong et al. 2005), food vacuoles were not apparent through epifluorescence microscope observations. In dilution experiments, the growth of these groups was almost balanced by the grazing loss (Table 4). This indicates that these phytoplankton groups were good prey items for microzooplankton. Based on cell sizes, the heterotrophic dinoflagellate Katodinium glaucum and ciliates were potentially major predators on these phytoplankters. In addition, rotifers ingested cryptophycean flagellates and Prorocentrum micans with CRs of $\sim 0.02 \mathrm{ml}$ ind. ${ }^{-1} \mathrm{~h}^{-1}$, comparable to values obtained for rotifers feeding on microflagellates in Chesapeake Bay (Dolan \& Gallegos 1991). Furthermore, the cyclopoid copepod Oithona davisae (including nauplii stages) is known to feed on microflagellates (Uchima \& Hirano 1986). Thus, each group of microzooplankton seems to contribute substantially to the grazing loss of $P$. micans and cryptophycean flagellates.

\section{Diatoms}

Skeletonema costatum and Chaetoceros debilis showed high $\mu_{\mathrm{n}}\left(>1 \mathrm{~d}^{-1}\right)$, but their grazing loss in dilution experiments was not significant or was very low (Table 4). Since some species of rotifers (Johansson 1987) and cyclopoids (Turner 1986, Beaumont et al. 2002) are known to graze upon diatoms, the results of the dilution experiments might be questioned. However, grazing experiments with rotifers showed no substantial grazing on $S$. costatum, while rotifers feed actively on Prorocentrum micans and cryptophycean flagellates (Fig. 4). In addition, previous laboratory and field experiments indicated that Oithona davisae do not feed on diatoms during any of this copepod's developmental stages (Uchima \& Hirano 1986, Uchima 1988). Since adults and copepodites of cyclopoids were almost exclusively composed of $O$. davisae and most of the copepod nauplii were cyclopoids (probably $O$. davisae) in the dilution experiments, the contributions of cyclopoids to diatom grazing were thus considered negligible in our study area. Observations of Katodinium glaucum and ciliates by epifluorescence microscopy showed no evidence of diatom grazing by protozoans in dilution experiments.

In the dilution experiments of Run 4 in 2004, $g$ values for Skeletonema costatum were small but significant ( $\mathrm{p}<0.05$; Table 4), suggesting that some microzooplankton species fed on the diatom. However, we could not identify the causative species.

\section{Zooplankton}

Although the ecology of freshwater rotifers is well known (e.g. Stemberger 1981 and references therein), information on oceanic rotifers is rather limited (Hernroth 1983, Johansson 1987, Arndt et al. 1990, Dolan \& Gallegos 1991). In our study area, Synchaeta spp. was abundant in 2002 and 2004 and its abundance exceeded 150 ind. $1^{-1}$ at the surface on most sampling dates. In addition, the abundance in 2003 was several 10 s of ind. $\mathrm{l}^{-1}$. These results indicate that rotifers in Ariake Sound were not a transient component, but rather constituted an important 
portion of the microzooplankton. CRs for rotifers grazing on microflagellates were $\sim 20 \mu \mathrm{l}$ ind. ${ }^{-1} \mathrm{~h}^{-1}$ (i.e. modest estimation); consequently, rotifers with an abundance of 500 ind. $\mathrm{l}^{-1}$ (the maximum value throughout the survey period) could clear $24 \%$ of the water per day. This indicates that rotifers can have a substantial grazing impact on microflagellates. However, grazing experiments were not conducted in duplicate, and rotifer abundance in the field was only monitored at a single station in the present study. Thus, these estimations should be used as a kind of test-calculation, and more detailed studies are required to understand the ecological roles of rotifers in Ariake Sound.

Enrichment of mesozooplankton to 5 times the natural level caused $\leq 0.1 \mathrm{~d}^{-1}$ decreases in $k_{\mathrm{n}}$ of phytoplankton (Table 5), indicating that grazing by the mesozooplankton population was not substantial. The main component of the mesozooplankton population in the experiments was Noctiluca scintillans ( 150 ind. $\mathrm{l}^{-1}$; Table 5). Using a CR of $3.5 \times 10^{-4} 1$ ind. ${ }^{-1} \mathrm{~d}^{-1}$ (Nakamura 1998) and the abundance $\left(N_{\mathrm{Z}}\right)$ of $\sim 150$ ind. $\mathrm{l}^{-1}$, a decrease in $k_{\mathrm{n}}$ of the phytoplankton due to $N$. scintillans grazing (i.e. CR $N_{\mathrm{Z}}$ ) would be $0.06 \mathrm{~d}^{-1}$, comparable with the observed decrease. In contrast, copepodites of Paracalanus parvus were present at abundances of $\sim 2$ ind. $1^{-1}$ in the mesozooplankton grazing experiments. As the CR of adult $P$. parvus was $\sim 50 \mathrm{ml}$ ind..$^{-1} \mathrm{~d}^{-1}$ (Suzuki et al. 1999), the decrease in $k_{\mathrm{n}}$ by $P$. parvus grazing would be $0.1 \mathrm{~d}^{-1}$ if CRs of the copepodites in the grazing experiment were comparable with those of the adults. However, the sizes of the copepodites in the grazing experiments were much smaller than those of adults (based on visual inspection), so grazing by $P$. parvus was probably not as substantial as that by N. scintillans.

The abundance of calanoid copepods in the mesozooplankton fraction $(>200 \mu \mathrm{m})$ was measured in 2004 (Table 2). The main species in this fraction was Paracalanus parvus (abundance 99 to 880 ind. $\mathrm{m}^{-3}$ ). Even assuming that all individuals of $P$. parvus were adults $\left(\mathrm{CR}=\sim 50 \mathrm{ml}\right.$ ind.$\left.^{-1} \mathrm{~d}^{-1}\right)$, the population clearance by the copepod would be 0.5 to $4.4 \% \mathrm{~d}^{-1}$. This further suggests that calanoid copepods did not contribute substantially to controlling phytoplankton abundance in 2004.

\section{Factors controlling phytoplankton community structure}

Except during a severe red tide composed of Akashiwo sanguinea (9 November 2004), nutrients were replete $\left(>2 \mu \mathrm{M}\right.$ of $\mathrm{NO}_{3}{ }^{-}+\mathrm{NO}_{2}{ }^{-}+\mathrm{NH}_{4}{ }^{+}$; Table 1) and did not seem to limit the growth rates of phytoplankton species in the field.
Diatoms showed high $\mu_{\mathrm{n}}\left(>1 \mathrm{~d}^{-1}\right.$; Table 4), and their mortality due to microzooplankton and mesozooplankton grazing was negligible. However, they were not as dominant as Akashiwo sanguinea, indicating that other factors suppressed their dominance. In situ growth experiments showed that the growth rates of Skeletonema costatum were low at $2 \mathrm{~m}$ depth (Fig. 3), and light limitation apparently prevented the diatoms from gaining dominance. In contrast, A. sanguinea accumulated at the surface layer in the daytime (Table 2; Park et al. 2002a), and thus could avoid light limitation. Prorocentrum micans and cryptophycean flagellates also accumulated at the surface layer, but the degree of accumulation was not as conspicuous as that of $A$. sanguinea (Table 2).

Prorocentrum micans and cryptophycean flagellates were actively grazed on by microzooplankton populations (Table 4). The growth of these phytoplankters was almost balanced with grazing losses, and sometimes grazing losses exceeded the growth rates. Thus, even though these phytoplankters could avoid light limitation, their populations were kept low by heavy grazing impacts.

Predation on Akashiwo sanguinea was limited to the ciliate Tiarina fusus in the present study; rotifers, cyclopoid copepods and protozoans (except for $T$. fusus) did not feed on the dinoflagellate effectively. In addition, the growth rates of $A$. sanguinea exceeded the grazing losses to $T$. fusus even when this ciliate was abundant. Thus, the scarcity of a predator, together with the ability of $A$. sanguinea to avoid light limitation has probably led to the persistent dominance of this dinoflagellate in Ariake Sound, despite its moderate to low growth rates.

\section{CONCLUSIONS}

Our survey and experiments, conducted over 3 years, revealed several characteristics of the plankton community structure in Ariake Sound (Fig. 5): turbid water and microzooplankton grazing prevented the dominance of diatoms and flagellates (Prorocentrum micans and cryptophycean flagellates), respectively, but the species with the ability to escape from light limitation and grazing pressure (Akashiwo sanguinea) dominated for a long period. In addition, the microzooplankton assemblage composed primarily of protozoans (including Tiarina fusus), rotifers and cyclopoid copepods was abundant. Although the fate of the microzooplankton was not examined in the present study, this should be clarified in the future in order to assess material cycling through plankton food webs. 


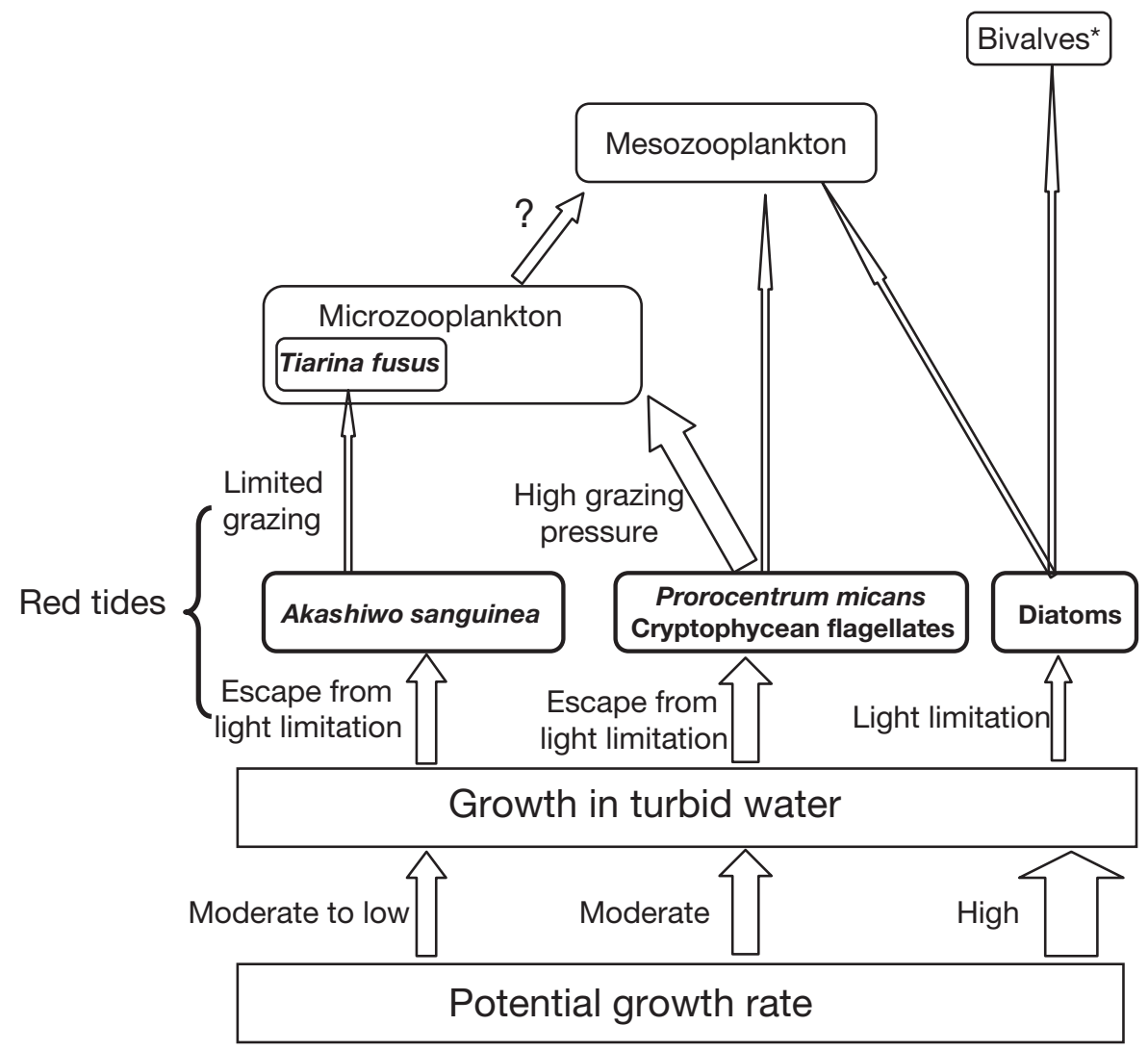

Fig. 5. Food web structure in Ariake Sound in late autumn, with emphasis on the fate of the phytoplankton assemblage. *: linkage between diatoms and bivalves; after Nakamura (2005)

Acknowledgements. The authors thank the staff of Ariake Fisheries Research and Development Center (AFRDC), especially I. Hakushima and Y. Kawamura, for permitting us to use AFRDC facilities, and for conducting nutrient analyses and engaging in helpful discussions. Thanks also to H. Katafuchi (a local fisherman) for supporting our field survey, K. Kusube, T. Nakazawa and N. Fujiwara for their technical assistance, and J. T. Turner for valuable comments and English editing.

\section{LITERATURE CITED}

Arndt H, Schroeder C, Schnese W (1990) Rotifers in the genus Synchaeta-an important component in the coastal waters of the southern Baltic. Limnologica 21:233-235

Beaumont KL, Nash GV, Davidson AT (2002) Ultrastructure, morphology and flux of microzooplankton faecal pellets in an east Antarctic fjord. Mar Ecol Prog Ser 245:133-148

Bockstahler KR, Coats DW (1993) Grazing of the mixotrophic dinoflagellate Gymnodinium sanguineum on ciliate populations of Chesapeake Bay. Mar Biol 116:477-487

Coats DW, Adam EJ, Gallegos CL, Hedrick S (1996) Parasitism of photosynthetic dinoflagellates in a shallow subestuary of Chesapeake Bay, USA. Aquat Microb Ecol 11:1-9

Daugbjerg N, Hansen G, Larsen J, Moestrup O (2000) Phylogeny of some of the major genera of dinoflagellates based on ultrastructure and partial LSU rDNA sequence data, including the erection of three new genera of un- armored dinoflagellates. Phycologia 39:302-307

Dolan JR, Gallegos CL (1991) Trophic coupling of rotifers, microflagellates, and bacteria during fall months in the Rhode River Estuary. Mar Ecol Prog Ser 77:147-156

Dolan JR, Gallegos CL, Moigis A (2000) Dilution effects on microzooplankton in dilution grazing experiments. Mar Ecol Prog Ser 200:127-139

Frost BM (1972) Effects of size and concentration of food particles on the feeding behavior of the marine planktonic copepod Calanus pacificus. Limnol Oceanogr 17:805-815

Hernroth L (1983) Marine pelagic rotifers and tintinnids important trophic links in the spring plankton community of the Gullmar Fjord, Sweden. J Plankton Res 5:835-846

Islam MS, Ueda H, Tanaka M (2005) Spatial distribution and trophic ecology of dominant copepods associated with turbidity maximum along the salinity gradient in a highly embayed estuarine system in Ariake Sea, Japan. J Exp Mar Biol Ecol 316:101-115

Jeong HJ, Yoon JY, Kim JS, Yoo YD, Seong KA (2002) Growth and grazing rates of the prostomatid ciliate Tiarina fusus on red-tide and toxic algae. Aquat Microb Ecol 28: 289-297

Jeong HJ, Yoo YD, Park JY, Song JY, Kim ST, Lee SH, Kim KY, Yih WH (2005) Feeding by phototrophic red-tide dinoflagellates: five species newly revealed and six species previously known to be mixotrophic. Aquat Microb Ecol 40:133-150

Johansson S (1987) Factors influencing the occurrence of males in natural populations of Synchaeta spp. Hydro- 
biologia 147:323-327

Juhl AR, Murell MC (2005) Interactions between nutrients, phytoplankton growth, and microzooplankton grazing in a Gulf of Mexico estuary. Aquat Microb Ecol 38:147-156

Kawamura Y, Kitajima H, Ozumi C, Yamashita Y (1986) Detailed environment on the offing Rokkaku River mouth. I. Relationship between diatom and water temperature, salinity, nutrients. Bull Saga Pref Ariake Fish Res Dev Cent 10:71-88 (in Japanese with English abstract)

Landry MR, Hasset RP (1982) Estimation of grazing impact of marine microzooplankton. Mar Biol 67:283-288

Loeblich AR III (1967) Aspects of the physiology and biochemistry of the Pyrrophyta. Phykos 5:216-255

Nakamura Y (1998) Biomass, feeding and production of NoCtiluca scintillans in the Seto Inland Sea, Japan. J Plankton Res 20:2213-2222

Nakamura Y (2005) Suspension feeding of the ark shell Scapharca subcrenata as a function of environmental and biological variables. Fish Sci 71:875-883

Nakamura Y, Suzuki S, Hiromi J (1995) Growth and grazing of a naked heterotrophic dinoflagellate, Gyrodinium dominans. Aquat Microb Ecol 9:157-164

Nakamura Y, Suzuki S, Hiromi J (1996) Development and collapse of a Gymnodinium mikimotoi red tide in the Seto Inland Sea. Aquat Microb Ecol 10:131-137

Nakamura Y, Hashizume K, Koyama K, Tamaki A (2005) Effects of salinity on sand burrowing activity, feeding and growth of the clams Mactra veneriformis, Ruditapes philippinarum, and Meretrix lusoria. J Shellfish Res 24:1053-1059

Nakata H (2004) The environmental system of Ariake Sound and its present situation. In: Tamaki A (ed) Proceedings of the symposium on 'Ecology of large bioturbators in tidal flats and shallow sublittoral sediments - from individual behavior to their role as ecosystem engineers'. Nagasaki University, p 67-70

Park MG, Cooney SK, Kim JS, Coats DW (2002a) Effects of parasitism on diel vertical migration, phototaxis/geotaxis,

Editorial responsibility: Klaus Jürgens,

Rostock, Germany and swimming speed of the bloom-forming dinoflagellate Akashiwo sanguinea. Aquat Microb Ecol 29:11-18

Park MG, Cooney SK, Yih W, Coats DW (2002b) Effects of two strains of the parasitic dinoflagellate Amoebophrya on growth, photosynthesis, light absorption, and quantum yield of bloom-forming dinoflagellates. Mar Ecol Prog Ser 227:281-292

Pedersen MF, Hansen PJ (2003) Effects of high pH on a natural marine planktonic community. Mar Ecol Prog Ser 260: 19-31

Sato M, Azuma M, Sato S, Kato N, Ichikawa T (2001) What is going on in Isahaya Bay and Ariake Sound? Sci J Kagaku 71:882-894 (in Japanese)

Stemberger RS (1981) A general approach to the culture of planktonic rotifers. Can J Fish Aquat Sci 38:721-724

Suzuki K, Nakamura Y, Hiromi J (1999) Feeding by the small calanoid copepod Paracalanus sp. on heterotrophic dinoflagellates and ciliates. Aquat Microb Ecol 17:99-103

Trimmer M, Gowen GJ, Stewart BM, Nedwell DB (1999) The spring bloom and its impact on benthic mineralization rates in western Irish Sea sediments. Mar Ecol Prog Ser 185:37-46

Turner JT (1986) Zooplankton feeding ecology: contents of fecal pellets of the cyclopoid copepods Oncaea venusta, Corycaeus amazonicus, Oithona plumifera, and O. simples from the northern Gulf of Mexico. PSZN I: Mar Ecol 7: 289-302

Uchima M (1988) Gut content analysis of neritic copepods Acartia omorii and Oithona davisae by a new method. Mar Ecol Prog Ser 48:93-97

Uchima M, Hirano R (1986) Food of Oithona davisae (Copepoda: Cyclopoida) and effect of food concentration at first feeding on the larval growth. Bull Plankton Soc Jpn 33: $21-28$

Umani SF, Beran A (2003) Several variations in the dynamics of microbial plankton communities: first estimates from experiments in the Gulf of Trieste, northern Adriatic Sea. Mar Ecol Prog Ser 247:1-16

Submitted: December 9, 2005; Accepted: April 24, 2006 Proofs received from author(s): July 18, 2006 